\title{
Dipyridamole: A New Liver Regeneration Agent
}

\author{
Dipiridamol: Yeni Bir Karaciğer Rejenerasyon Ajanı
}

\section{Özgün Araştrma \\ Research Article}

\author{
Hüseyin Esin $\odot$, Cem Karaali $\odot$, Mustafa Emiroğlu $\odot$, Hülya Akgün $\odot$, \\ Sebahattin Muhtaroğlu $\oplus^{\oplus}$ Zeki Yılmaz $^{\oplus}$
}

\section{ABSTRACT}

Objective: We assessed the effect of dipyridamole, a phosphodiesterase inhibitor, on liver regeneration in experimentally hepatectomized rats.

Methods: Sixty Wistar-Albino rats were divided into two groups as control and study groups. Each group has been divided into three subgroups containing 10 rats each. After $70 \%$ liver resection has been performed to the rats, upon resection dipyridamole infusion to the study group and $0.9 \% \mathrm{NaCl}$ infusion to the control group has been done. Rats were allowed to survive for 24,48 , and $72 \mathrm{~h}$ and then they were sacrificed. Relative liver weight, AST, $A L T$, ALP, albumin and PT were measured. Histopathologic assessment was obtained by mitotic index and proliferating cell nuclear antigen (PCNA) labeling index.

Results: There were statistically significant differences between study and control groups in ALP and relative liver weights at 24,48 , and $72 \mathrm{~h}(p<0.05)$.

There were also statistically significant differences between the groups in PT and albumin levels at $48 \mathrm{~h}$ for PT, and $24 h$ and $72 h$ for albumin levels ( $p<0.05)$. There were no statistically significant differences between study and control groups in AST and ALT at $48 \mathrm{~h}(p>0.05)$. Mitotic index and PCNA labeling index were significantly higher in study group for each time period ( $p<0.05)$.

Conclusion: The dipyridamole exogenously applied after partial hepatectomy has provided improvement in morphological, biochemical and histopathological parameters.

Keywords: Phosphodiesterase inhibitor, dipyridamole, liver, regeneration

\section{öz}

Amaç: Bu çalışmada, deneysel olarak parsiyel hepatektomi yapılan sıçanlarda karaciğer rejenerasyonu üzerine bir fosfodiesteraz inhibitörü olan dipiridamolün etkisini değerlendirmeyi amaç edindik.

Yöntem: Altmış Wistar-Albino cinsi sıçan kontrol ve çalışma grupları olarak iki gruba ayrıldı. Her grup, her biri 10 sıçan içeren üç alt gruba ayrılmıştır. Sıçanlara \%70 karaciğer rezeksiyonu yapıldıktan sonra, çalışma grubuna rezeksiyon sonrası dipiridamol infüzyonu ve kontrol grubuna \%0,9 NaCl infüzyonu yapıldı. Denekler hipovolemi oluşturmak sureti ile sakrifiye edilerek 24., 48. ve 72. saatlerde kalan karaciğer dokusu çıkarılarak tartıldı. Rölatif karaciğer ağırlığı, AST, ALT, ALP, albümin ve PT ölçüldü. Histopatolojik değerlendirme için mitotik indeks ve prolifere olan hücre nükleer antijen (PCNA) değerleri elde edildi.

Bulgular: Çalışma grubu ile kontrol grubu arasında, ALP ve rölatif karaciğer ağırlıkları arasında 24., 48. ve 72. saatlerde istatistiksel olarak anlamlı fark vardı $(p<0,05)$. Gruplar arasında PT ve albümin düzeylerinde PT için 48. saat, albümin düzeyleri için 24. ve 72. saat istatistiksel olarak anlamlı fark vardı $(p<0,05)$. Fakat AST ve ALT ölçümlerinde çalışma ve kontrol grupları arasında 48. saatte istatistiksel olarak anlamlı fark yoktu $(p>0,05)$. Mitotik indeks ve PCNA değerleri, her bir süre için çalışma grubunda anlamlı olarak daha yüksekti $(p<0,05)$.

Sonuç: Parsiyel hepatektomi sonrası ekzojen olarak uygulanan dipiridamol morfolojik, biyokimyasal ve histopatolojik parametrelerde iyileşme sağlamıştır.

Anahtar kelimeler: Fosfodiesteraz inhibitörü, dipiridamol, karaciğer, rejenerasyon
S. Muhtaroğlu 0000-0002-5644-2620 Erciyes Üniversitesi Tıp Fakültesi, Biokimya Bölümü, Kayseri, Türkiye

Z. Yilmaz 0000-0003-4715-0519 Erciyes Üniversitesi Tıp Fakültesi, Genel Cerrahi Bölümü, Kayseri, Türkiye

Cite as: Esin $\mathrm{H}$, Karaali C, Emiroğlu M, Akgün H, Muhtaroğlu S, Yılmaz Z. Dipyridamole: A new liver regeneration agent. Tepecik Eğit. ve Araşt. Hast. Dergisi. 2019;29(1):67-73.
(C) Telif hakkı TC. Să̆lkk Bakanlı̆̆ı İzmir Tepecik Eğit. ve Arast. Hastanesi. Logos Tip Yayınclık tarafindan yayınlanmaktadır. Bu dergide yayınlanan bütün makaleler Creative Commons Atf-GayriTicari 4.0 Uluslararası Lisansı ile lisanslanmıştr. (c) Copyright Association of Publication of the T.C. Ministry of Health İmir Tepecik Education and Research Hospital.

This journal published by Logos Medical Publishing.
Licenced by Creative Commons Attribution-NonCommercial 4.0 International (CC BY-NC 4.0) 


\section{INTRODUCTION}

The liver is a unique organ with a regeneration capacity, which is important for hepatocytes. This proliferation may occur in circumstances such as liver injury, liver tissue defect or various metabolic situations ${ }^{(1)}$. Liver resection is widely used in malignant liver disease, particularly in hepatocellular carcinoma. Liver regeneration after partial hepatectomy has been well researched in rodents, with regeneration after partial hepatectomy $(\mathrm{PH})$ in rats taking 10-14 days. Studies focused on understanding the liver regeneration and on new pharmacological developments are important. Studies on animals have demonstrated the effect of agents, such as silymarin (2), bicyclol (3), curcumin ${ }^{(4)}$, and amiodarone ${ }^{(5)}$ in increasing regeneration, but thus far, no studies have investigated the effect of dipyridamole on liver regeneration. Cellular cyclic adenosine monophosphate (cAMP) is a secondary messenger, and has an important role in cellular response to ischemia-reperfusion, toxic injury and surgical trauma. Increased intracellular cAMP levels have a protective role in the liver by stabilizing membranes in hepatocytes and endothelial cells. Intracellular CAMP concentration is elevated with adenylate cyclase enzyme activation and decreased with phosphodiesterase enzyme activation.

Phosphodiesterases (PDEs) catalyze the breakdown of $3^{\prime} 5^{\prime}$-cyclic nucleotide monophosphates, such as cyclic adenosine monophosphate (cAMP) and cyclic guanosine monophosphate (cGMP), which serve as important intracellular second messengers. Phosphodiesterase inhibitors increase the intracellular CAMP and CGMP. This increase in CAMP and CGMP levels elevates the ionized calcium levels in the myocardium and in vascular smooth muscle, resulting in prolonged vasodilation. Dipyridamole, an agent that has been used for several years as a coronary dilatator, acts as a nucleoside transport inhibitor and phosphodiesterase inhibitor ${ }^{(6-8)}$. It limits the adenosine cellular entrance, resulting in vasodilation and a decrease in the resistance of hepatic arterial blood flow. Dipyridamole also induces a protective effect for liver ischemia-reperfusion injury by increasing endogenous adenosine levels. We aimed to assess the effect of dipyridamole, a phosphodiesterase inhibitor, on liver regeneration in rats.

\section{MATERIALS and METHODS}

\section{Animals}

We used 60 Wistar albino rats, kept in standard cages and fed a standard rat diet and tap water, for the analyses.The rats' weight varied between 300 and $550 \mathrm{~g}$. We divided the rats into six groups: three control groups and three study groups.

\section{Experimental design}

Sixty rats were divided into two groups as control and study groups. The control and study groups were divided into three groups based on sacrifice time: 24, 48, and $72 \mathrm{~h}$ (Table 1).

Table 1. Properties of the control and study groups.

\begin{tabular}{llll}
\hline Group I & : Control group & $(24 h)$ & $(n=10)$ \\
Group II & $:$ Study group & $(24 h)$ & $(n=10)$ \\
Group III & $:$ Control group & $(48 h)$ & $(n=10)$ \\
Group IV & $:$ Study group & $(48 h)$ & $(n=10)$ \\
Group V & $:$ Control group & $(72 h)$ & $(n=10)$ \\
Group VI & $:$ Study group & $(72 h)$ & $(n=10)$
\end{tabular}

\section{Surgical procedure}

The rats were anesthetized with $50 \mathrm{mg} / \mathrm{kg}$ ketamine and $10 \mathrm{mg} / \mathrm{kg}$ xylazine administered intraperitoneally and disabled with spontaneous respiration during the experiment. Rats were weighed after anesthesia and weights were recorded. Before laparotomy, $25 \mathrm{mg} / \mathrm{kg}$ of cefazolin (Mustafa Nevzat Drug Industry; Istanbul, Turkey) was administered to prevent bacterial translocation from the jugular catheter (sefazolflakon jugular) used. In accordance with the method described by Higgins and colleagues ${ }^{(9)}$, the middle and left lateral lobes were tied from the joint of inferior vena cava by $4 / 0$ silk, i.e., a $70 \%$ liver resection was performed. The removed liver was weighed and preserved. After resection, we administered immediately single dose of $0.05 \mathrm{mg} / \mathrm{kg}$ dipyri- 
damole intravenously to the rats in the study groups. Saline infusion was continued for $6 \mathrm{~h}$, after which food was allowed orally ${ }^{(10)}$. The control groups did not receive dipyridamole after resection, but received saline infusion for the first $6 \mathrm{~h}$ and then food was allowed orally in the same manner as that for the study groups. Laparotomy was repeated in groups I and II at $24 \mathrm{~h}$, groups III and IV at $48 \mathrm{~h}$, and groups V and $\mathrm{VI}$ at $72 \mathrm{~h}$. Blood samples were collected from the vena cava inferior. The remaining liver was resected and weighed. Removed liver tissues were stored in $10 \%$ buffered formalin for pathological examination. No rats died after partial hepatectomy.

\section{Morphological parameters}

Relative liver weight: The liver weight on autopsy in the study groups was subtracted from the remaining weight of the liver after partial hepatectomy in the control groups. The ratio of the liver weight was calculated. The value obtained was multiplied by 100 to obtain a percentage restitution of the liver mass ${ }^{(11)}$. Results were expressed as percentages.

\section{Biochemical parameters}

Aspartateaminotransferase (AST), alanineaminotransferase (ALT), alkaline phosphatase (ALP), albumin, and prothrombin time (PT) were measured in the control and study groups.

\section{Mitotic index}

The liver tissue stored in the $10 \%$ formalin solution was processed in paraffin-embedded blocks and stained with hematoxylin and eosin. Mitotic index (MI) was described as the number of mitotic and total hepatocytes measured with a 30 high-power field and shown as a ratio to 1000 cells ${ }^{(12)}$.

\section{Proliferated cell nuclear antigen labeling index}

Paraffin- embedded liver tissue specimens were sectioned in $5 \mathrm{~mm}$ widths, and a proliferated cell nuclear antigen (PCNA) kit (Dako GmbH, Hamburg) was used for the immunohistochemical analyses. The number of cells colored with PCNA and total hepa- tocytes were measured with a 30 high-power field and shown as a ratio to 1000 cells ${ }^{(12)}$.

\section{Statistical analysis}

Data were presented as mean \pm standard error of the mean and mean (min-max.). Students-t tests were used to compare the control and study groups at 24 , 48 , and $72 \mathrm{~h}$. One-way analysis of variance was used to analyze the differences between variables at 24 , 48 , and $72 \mathrm{~h}$ in the control and study groups.

We used Statistical Package for the Social Sciences (SPSS) Version 19.0 for the statistical analyses. Significance was set at $p<0.05$.

\section{RESULTS}

\section{Relative liver weight results}

Relative liver weights were compared at 24,48 , and $72 \mathrm{~h}$ in the control and study groups. There were statistically significant differences for each of the three time periods between the control ( $24 \mathrm{~h}, 11.46 \pm 3.2$; 48 h, 24.77 \pm 5.41 ; and 72 h, 24.49 \pm 5.05$)(p<0.001)$ and study groups ( $24 \mathrm{~h}, 21.47 \pm 5.03$; $48 \mathrm{~h}, 34.31 \pm 7.94$; and $72 h, 48.33 \pm 3.63)(p<0.001)$. There were also statistically significant differences in the three periods within study groups $(p<0.001)$.

\section{Evaluation of albumin and liver enzymes levels}

Both AST and ALT levels increased after partial hepatectomy. When we compared the control and study groups, AST and ALT levels were significantly lower at 24 and $72 \mathrm{~h}$. AST levels were significantly different at 24 and $72 \mathrm{~h}$ in the control groups, and were significantly different at each time point in the study groups $(p<0.001)$. ALT levels were significantly different at all three time points in the control and study groups ( $p=0.002, p<0.001$ respectively).

When the study and control groups were compared, ALP levels were significantly different between the groups at each time point. 
Albumin levels significantly differed at 24 and $72 \mathrm{~h}$ between the control and study groups $(p=0.015$, $p=0.035$ respectively). There were also significant differences between 24 and 48 h, 24 and $72 \mathrm{~h}$ in the study groups $(p=0.003)$.

\section{Hematological results}

\section{Prothrombine time results}

Significantly difference was detected in PT levels obtained at $48 \mathrm{~h}$ between the control and study gro- ups $(p=0.015)$. There were also significant differences in each time period in the study and control groups separately $(p<0.001)$.

\section{Mitotic index and prolferated cell nuclear antigen labeling index}

MI was significantly higher at 24,48 , and $72 \mathrm{~h}$ in the study group than in the control groups $(p<0.001)$. The PCNA labeling index was also significantly higher in the study group than the control groups at each time period. The PCNA labeling index and MI reac-

Table 2. Analysis of differences at each time period in the control groups.

\begin{tabular}{|c|c|c|c|c|c|}
\hline Groups & Parameter & 24. Hour & 48. Hour & 72. Hour & p \\
\hline \multirow[t]{8}{*}{ Control } & Relative weight (\%) ( $\mathrm{x} \pm \mathrm{ss})$ & $11.46 \pm 3.21^{\mathrm{a}}$ & $24.78 \pm 5.42^{\mathrm{b}}$ & $24.49 \pm 5.05^{b}$ & $p<0.001$ \\
\hline & AST & $1482.70 \pm 1099.41^{\mathrm{a}}$ & $561.10 \pm 390.73^{b}$ & $210.90 \pm 74.49^{b}$ & $P=0.001$ \\
\hline & ALT & $622.30 \pm 510.70^{\mathrm{a}}$ & $245.30 \pm 155.33^{b}$ & $91.30 \pm 45.15^{b}$ & $P=0.002$ \\
\hline & ALP & $300.10 \pm 53.13^{a}$ & $397.80 \pm 69.72^{\mathrm{a}}$ & $553.30 \pm 172.44^{b}$ & $p<0.001$ \\
\hline & Albumine & $2.73 \pm 0.24^{\mathrm{a}}$ & $2.67 \pm 0.25^{\mathrm{a}}$ & $2.63 \pm 0.15^{\mathrm{a}}$ & $P=0.588$ \\
\hline & PT & $19.56 \pm 0.66^{\mathrm{a}}$ & $17.53 \pm 0.83^{b}$ & $16.42 \pm 0.86^{c}$ & $p<0.001$ \\
\hline & Ml (\%o) & $3.20 \pm 0.91^{\mathrm{a}}$ & $6.70 \pm 1.70^{\mathrm{b}}$ & $3.80 \pm 0.78^{a}$ & $p<0.001$ \\
\hline & PCNA (\%о) & $5.90 \pm 2.13^{\mathrm{a}}$ & $8.40 \pm 1.07^{b}$ & $6.00 \pm 1.63^{a}$ & $P=0.003$ \\
\hline
\end{tabular}

- According to multiple mixing test results; alphabetical superscripts above average $(a, b, c)$ are to illustrate that similar letters shows the similarity among groups, while dissimilar ones shows the diversity of the groups.

Table 3. Analysis of differences at each time period in the dipyridamole groups.

\begin{tabular}{|c|c|c|c|c|c|}
\hline Groups & Parameter & 24. Hour & 48. Hour & 72. Hour & $\mathbf{p}$ \\
\hline \multirow[t]{8}{*}{ Dypridamole } & Relative weight (\%) & $21.47 \pm 5.03^{\mathrm{a}}$ & $34.31 \pm 7.94^{b}$ & $48.33 \pm 3.63^{c}$ & $p<0.001$ \\
\hline & AST & $564.6 \pm 187.61^{\mathrm{a}}$ & $309.6 \pm 136.38^{b}$ & $133.6 \pm 17.51^{c}$ & $p<0.001$ \\
\hline & ALT & $322.2 \pm 136.7^{a}$ & $134.1 \pm 40.55^{b}$ & $46.3 \pm 20.36^{b}$ & $p<0.001$ \\
\hline & ALP & $218.8 \pm 43.53^{a}$ & $311.3 \pm 68.81^{b}$ & $398.1 \pm 93.77^{c}$ & $p<0.001$ \\
\hline & Albumine & $3.11 \pm 0.37^{a}$ & $2.7 \pm 0.14^{b}$ & $2.8 \pm 0.18^{b}$ & $P=0.003$ \\
\hline & PT & $19.38 \pm 0.62^{a}$ & $18.41 \pm 0.61^{b}$ & $16.75 \pm 0.64^{c}$ & $p<0.001$ \\
\hline & MI (\%o) & $7.9 \pm 1.91^{\mathrm{a}}$ & $11.2 \pm 1.68^{b}$ & $9.3 \pm 1.94^{a}$ & $p=0.002$ \\
\hline & PCNA (\%о) & $13.9 \pm 2.02^{\mathrm{a}}$ & $20.9 \pm 3.03^{b}$ & $14.7 \pm 1.06^{a}$ & $p<0.001$ \\
\hline
\end{tabular}

- According to multiple mixing test results; alphabetical superscripts above average $(a, b, c)$ are to illustrate that similar letters shows the similarity among groups, while dissimilar ones show the diversity of the groups.

Table 4. Analyses for the study and control groups at each time periods.

\begin{tabular}{|c|c|c|c|c|c|c|c|c|c|}
\hline \multirow{2}{*}{$\begin{array}{l}\text { Groups } \\
\text { Parameters }\end{array}$} & \multicolumn{2}{|c|}{$24 \mathrm{H}$} & \multicolumn{2}{|c|}{$48 \mathrm{H}$} & \multicolumn{2}{|c|}{$72 \mathrm{H}$} & \multirow[b]{2}{*}{ P1 } & \multirow[b]{2}{*}{ P2 } & \multirow[b]{2}{*}{ P3 } \\
\hline & Control & Dypridamole & Control & Dypridamole & Control & Dypridamole & & & \\
\hline $\begin{array}{l}\text { Relative } \\
\text { Weight (\%) }\end{array}$ & $11.46 \pm 3.20$ & $21.47 \pm 5.03$ & $24.77 \pm 5.41$ & $34.31 \pm 7.94$ & $24.49 \pm 5.05$ & $48.33 \pm 3.63$ & $<0.001$ & $=0.006$ & $<0.001$ \\
\hline AST & $1482.70 \pm 1099.40$ & $564.60 \pm 187.61$ & $561.10 \pm 390.72$ & $309.60 \pm 136.38$ & $210.90 \pm 74.48$ & $133.60 \pm 17.51$ & $=0.027$ & $=0.071$ & $=0.01$ \\
\hline ALT & $622.30 \pm 510.69$ & $322.22 \pm 136.70$ & $245.30 \pm 155.33$ & $134.10 \pm 40.56$ & $91.30 \pm 45.15$ & $46.30 \pm 20.36$ & $=0.01$ & $=0.053$ & $=0.01$ \\
\hline ALP & $300.10 \pm 53.12$ & $218.80 \pm 43.53$ & $397.80 \pm 69.71$ & $311.30 \pm 68.81$ & $553.30 \pm 172.43$ & $398.10 \pm 93.77$ & $=0.001$ & $=0.012$ & $=0.022$ \\
\hline Albumine & $2.73 \pm 0.24$ & $3.11 \pm 0.37$ & $2.67 \pm 0.247$ & $2.70 \pm 0.14$ & $2.63 \pm 0.14$ & $2.80 \pm 0.18$ & $=0.015$ & $=0.741$ & $=0.035$ \\
\hline PT & $19.56 \pm 0.66$ & $19.38 \pm 0.62$ & $17.53 \pm 0.83$ & $18.41 \pm 0.61$ & $16.42 \pm 0.86$ & $16.75 \pm 0.64$ & $=0.542$ & $=0.015$ & $=0.347$ \\
\hline MI (\%०) & $3.20 \pm 0.91$ & $7.90 \pm 1.91$ & $6.70 \pm 1.70$ & $11.20 \pm 1.68$ & $3.80 \pm 0.78$ & $9.30 \pm 1.94$ & $<0.001$ & $<0.001$ & $<0.001$ \\
\hline PCNA (\%०) & $5.90 \pm 2.13$ & $13.90 \pm 2.02$ & $8.40 \pm 1.07$ & $20.90 \pm 4.05$ & $6.00 \pm 1.63$ & $14.70 \pm 1.05$ & $<0.001$ & $<0.001$ & $<0.001$ \\
\hline
\end{tabular}


hed the highest levels at $48 \mathrm{~h}$, and both decreased at 72 hour.

There were significant differences in $\mathrm{MI}$ and PCNA labeling index within the study and control groups at 24,48 , and $72 \mathrm{~h}(\mathrm{p}<0.001)$.

The mean \pm standard error of the mean and results of the analyses of relative liver weight, AST, ALT, ALP, albumin, PT, MI, PCNA are shown in Tables 2 and 3. The analyses for the study and control groups at 24 , 48, and $72 \mathrm{~h}$ are shown in Table 4.

\section{DISCUSSION}

We demonstrated that dipyridamole exogenously administered after partial hepatectomy resulted in improvement in morphological, biochemical and histopathological parameters. The hepatic regeneration rate is a parameter used to investigate the effectiveness of materials used in hepatic regeneration studies ${ }^{(13)}$. A study by Limura ${ }^{(14)}$ on mitosis ratios in rats found peaks at 24 and $48 \mathrm{~h}$ after partial hepatectomy. In our study, regeneration rates at 24,48 , and $72 \mathrm{~h}$ were $11.5 \%, 24.8 \%$ and $24.5 \%$ in the control groups and $21 \%, 34 \%$ and $48.3 \%$ in the study groups with dipyridamole, respectively. These differences were statistically significant $(p<0.05)$, indicating that dipyridamole increased liver regeneration morphologically. The difference between regeneration rates at 48 and $72 \mathrm{~h}$ in the control groups was quite small $(p<0.05)$, but the difference in the study groups was statistically much larger $(p<0.05)$. Therefore, dipyridamole may be useful in liver resection performed for various benign and malignant hepatic and biliary diseases.

Dipyridamole may reduce hepatocellular damage and promote an earlier return to normal liver function. Liver function tests, such as AST, ALT, GGT and $A L P$, were affected by the amount of remaining liver after hepatic surgery rather than liver function itself ${ }^{(15)}$. However these tests are better at indica- ting acute hepatocellular injury ${ }^{(1)}$. In this study, AST, ALT, and ALP levels were significantly lower in the study groups than in the control groups $(p<0.05)$.

We considered that albumin would not give sufficient information in the early stages after hepatectomy. Albumin levels are used to evaluate patients' nutritional levels and/or liver functions ${ }^{(16)}$, and albumine is a valuable measure because it is only synthesized in the liver. We found no significant difference in albumin levels between the study and control groups at $48 \mathrm{~h}$, but albumin levels were higher in the study groups than in the control groups at 24 and 72 $h(p<0.05)$. This increase might be explained by an increase in liver capacity. However, this is not a reliable parameter in cases such as inflammation, liver diseases, and surgical trauma ${ }^{(16)}$. Non-specific factors, such as postoperative assist or hemodilution, may also affect serum albumin levels ${ }^{(17)}$.

Dipyridamole may be effective in reducing bleeding diathesis after hepatectomy and may be effective in preventing hepatic failure postoperatively. PT values may also provide preoperative or posyoperative information about the liver ${ }^{(15)}$. Serum bilirubin levels and PT are not controversial as AST, ALT, ALP and albumin in assessing the synthesis ability of the liver. Various studies, it is used to assess the synthesis ability of liver ${ }^{(15,18)}$. In our study, there was no statistically significant difference in the comparison of PT values between the study and control groups at 24 and $72 \mathrm{~h}$. At $48 \mathrm{~h}$, when regeneration reached its highest level, we detected a statistically significant difference between the study and control groups $(p<0.05)$. Liver bleeding is most frequent at $48 \mathrm{~h}$ postoperatively ${ }^{(19)}$. Our study suggests that dipyridamole may reduce bleeding complications.

We determined that dipyridamole increases $\mathrm{MI}$. PCNA and MI are used instead of liver weight to assess the liver regeneration ${ }^{(3,4)}$. $\mathrm{Ml}$ is a commonly used proliferation index, because it is easy to evalu- 
ate. Under normal conditions, no mitotic activity is observed in an undamaged liver. However, mitotic activity increases in the remaining tissue after hepatic resection ${ }^{(4,10)}$. Laconi et al. showed that the number of mitotic cells was higher at 24 and $48 \mathrm{~h}$ than at 72 and $144 \mathrm{~h}$ after $70 \%$ hepatic resection in rats. Toydemir et al. ${ }^{(4)}$ found higher $\mathrm{Ml}$ in a group that was administered curcumin after partial hepatectomy than a group that was administered a placebo after partial hepatectomy. A study by Yao et al. ${ }^{(3)}$ found no statistically significant differences in $\mathrm{MI}$ between partial hepatectomy and partial hepatectomy plus bicylol groups at 24 and $48 \mathrm{~h}$. In this study, $\mathrm{MI}$ rates in the control groups were $3.2 \%$, $6.7 \%$ and $3.8 \%$ at 24,48 and $72 \mathrm{~h}$, respectively and in the study groups were7.9\%o, $11.2 \%$ ond $9.3 \%$, respectively. As noted above some agents, including dipyridamole increase MI.

We found that dipyridamole increased the PCNA labeling index at all three time points after partial hepatectomy. PCNA determined immunocytochemically shows the proliferative activity of cells by measuring the percentage of cells in the $S$ phase ${ }^{(20)}$. In evaluating regeneration, Kogure et al. ${ }^{(21)}$ reported that labeling with PCNA begins at $24 \mathrm{~h}$, reached the highest level at $48 \mathrm{~h}$, and lowered at $72 \mathrm{~h}$. Yao et al. (3) found that PCNA rates increased more in a bicyclol plus partial hepatectomy group than in a placebo plus partial hepatectomy group. Selzner and Clavien ${ }^{(10)}$ reported PCNA rates of was $23 \%$ at $24 \mathrm{~h}, 25 \%$ ot $48 \mathrm{~h}$ after hepatectomy. In the present study, the PCNA labeling index was higher in the study groups than in the control groups $(p<0.05)$. We demonstrated that regeneration increased, continued faster, and the liver regenerated over a shorter time period when dipyridamole was administered.

The limitations of the study were that we did not evaluate liver regeneration radiologically, and the study would have benefited from a longer follow-up period.

\section{CONCLUSION}

We found that the dipyridamole exogenously administered after partial hepatectomy resulted in the improvement of morphological, biochemical, and histopathological parameters. Dipyridamole may also be effective in preventing complications such as hepatic failure and bleeding that increase morbidity and mortality after liver resection. By increasing regeneration after partial hepatectomy, dipyridamole may also be effective in promoting a faster return to normal life for patients and a shortened hospital stay. Phosphodiesterase inhibitors are easily accessible and affordable, and the side effect profiles in humans are well understood. Therefore, dipyridamole may be a useful agent to reduce mortality and morbidity after hepatic resection.

Ethics Committee Approval: Before the study, approval was obtained from Erciyes University Faculty of Medicine Ethics Committee (Decision no: 05-163).

Conflict of Interest: The authors declared that there was no conflict of interest in the preparation and publication of this manuscript.

Funding: This study supported by a grant from Erciyes University Medical Faculty Research

Etik Kurul Onayı: Çalışma öncesinde Erciyes Üniversitesi Tıp Fakültesi Etik Kurulunun onayı alındı (Karar no: 05-163).

Çıkar Çatışması: Yazarlar bu yazının hazırlanması ve yayınlanması aşamasında herhangi bir çıkar çakışması olmadığını beyan etmişlerdir.

Finansal Destek: Bu çalışma, Erciyes Üniversitesi Tıp Fakültesi Araştırması hibesi ile desteklenmiştir.

\section{REFERENCES}

1. Elaine YC, Ali Z, David AG, John AG and Ronald WB. Liver, Brunicardi FC. Schwartz'sPrinciples of Surgery. $10^{\text {th }}$ Int. ed. McGraw-Hill, Philadelphia; 2015; p. 1269.

2. Wu J, Tsai C, Yeh Y, Lin Y-M, Lin C, Day CH, et al. Silymarin Accelerates Liver Regeneration after Partial Hepatectomy. Evidence-Based Complement Altern Med. 2015;2015:1-14. [CrossRef]

3. Yao XM, Zhao J, Li W, Li Y. Effects of bicyclol on liver regeneration after partial hepatectomy in rats. Dig Dis Sci. 2009;54(4):774-81. [CrossRef]

4. Toydemir T, Kanter M, Erboga M, Oguz S, Erenoglu C. Antioxidative, antiapoptotic, and proliferative effect of cur- 
cumin on liver regeneration after partial hepatectomy in rats. Toxicol Ind Health. 2013;31(2):162-72. [CrossRef]

5. Lin C-W, Chen Y-S, Lin C-C, Chen Y-J, Lo G-H, Lee P-H, et al. Amiodarone as an autophagy promoter reduces liver injury and enhances liver regeneration and survival in mice after partial hepatectomy. Sci Rep. 2015;5 Oct 30;5:15807. [CrossRef]

6. Bender AT, Beavo JA. Cyclic Nucleotide Phosphodiesterases: Molecular Regulation to Clinical Use. Pharmacol Rev. 2006 Sep 1;58(3):488-520. [CrossRef]

7. Conti M, Beavo J. Biochemistry and Physiology of Cyclic Nucleotide Phosphodiesterases: Essential Components in Cyclic Nucleotide Signaling. Annu Rev Biochem. 2007;76(1):481-511. [CrossRef]

8. Brown DG, Wilkerson EC, Love WE. A review of traditional and novel oral anticoagulant and antiplatelet therapy for dermatologists and dermatologic surgeons. J Am Acad Dermatol. 2015 Mar;72(3):524-34. [CrossRef]

9. Higgins GM, Anderson RM. Experimental pathology of the liver: Restoration of the liver on the white rat following partial surgical removal. Arch Pathol. 1931;12:186-202.

10. Taniguchi M, Magata S, Suzuki T, Shimamura T, Jin MB, lida J, et al. Dipyridamole protects the liver against warm ischemia and reperfusion injury. J Am Coll Surg. 2004;198(5):758-69. [CrossRef]

11. Fishback FC. A morphologic study of regeneration of the liver after partial removal. Arch Pathol. 1929;7:956-77.

12. Selzner M, Clavien $P$ a. Failure of regeneration of the steatotic rat liver: disruption at two different levels in the regeneration pathway. Hepatology. 2000;31(1):35-42. [CrossRef]

13. Okano T, Tsubouchi T, Yamashita Y, Wakanabayashi H, Tanaka S. Hepatic protein synthesis in the regenerating rat liver after hepatopancreatectomy. Surgery Today. 1997;27:511. [CrossRef]
14. limuro $Y$, Nishiura T, Hellerbrand $C$, Behrns KE, Schoonhoven R, Grisham JW, et al. NFkappaB prevents apoptosis and liver dysfunction during liver regeneration. J Clin Invest. 1998;101(4):802-11. [CrossRef]

15. Balzan S, Belghiti J, Farges O, Ogata S, Sauvanet A, Delefosse D, Durand F.The "50-50 criteria"on postoperative day 5:an accurate predictor of liver failure and death after hepatectomy. Ann Surg. 2005 Dec;242(6):824-8 discussion 828-9. cros. reff.

16. Hülshoff A, Schricker T, Elgendy H, Hatzakorzian R, Lattermann R. Albumin synthesis in surgical patients. Nutrition. 2013;29(5):703-7. [CrossRef]

17. Fan ST, Lo CM, Lai EC, Chu KM, Liu CL, Wong J. Perioperative nutritional support in patients undergoing hepatectomy for hepatocellular carcinoma. N Engl J Med. 1994;331(23):154752. [CrossRef]

18. Imamura H, Seyama Y, Kokudo N, Maema A, Sugawara $Y$, Sano K, et al. One thousand fifty-six hepatectomies without mortality in 8 years. Arch Surg. 2003;138(11):1198-206; discussion 1206. [CrossRef]

19. Kauffmann R, Fong Y. Post-hepatectomy liver failure. Hepatobiliary Surg Nutr. 2014 Oct;3(5):238-46. [CrossRef]

20. Hall PA, Levison DA, Woods AL, Yu CCW, Kellock DB, Watkins $J A$, et al. Proliferating cell nuclear antigen (PCNA) immunolocalization in paraffin sections: An index of cell proliferation with evidence of deregulated expression in some neoplasms. J Pathol. 1990;162(4):285-94. [CrossRef]

21. Kogure K, Zhang YQ, Shibata H, Kojima I. Immediate onset of DNA synthesis in remnant rat liver after $90 \%$ hepatectomy by an administration of follistatin. J Hepatol. 1998;29(6):97784. [CrossRef] 